\title{
Structuring wicked problems in transdisciplinary research using the Social-Ecological systems framework: An application to the montado system, Alentejo, Portugal
}

\author{
Maria Helena Guimarães a, *, Nuno Guiomar ${ }^{a}$, Diana Surová a , Sérgio Godinho a , \\ Teresa Pinto Correia ${ }^{\mathrm{a}}$, Audun Sandberg ${ }^{\mathrm{b}}$, Federica Ravera ${ }^{\mathrm{c}}$, Marta Varanda ${ }^{\mathrm{d}}$ \\ ${ }^{a}$ Instituto de Ciências Agrárias e Ambientais Mediterrânicas (ICAAM), University of Évora, Núcleo da Mitra, Edifício Principal, Apartado 94, 7002-554 Évora, \\ Portugal \\ ${ }^{\mathrm{b}}$ Nord University, NO-8049, Bodø, Norway \\ ${ }^{c}$ Universitat de Vic- Universitat Central de Catalunya, 08500 Vic, Spain \\ d SOCIUS/Instituto Superior de Economia e Gestão, Universidade de Lisboa, Lisbon, Portugal
}

\section{A R T I C L E I N F O}

Article history:

Received 9 October 2017

Received in revised form

20 April 2018

Accepted 22 April 2018

Available online 25 April 2018

\section{Keywords:}

Transdisciplinarity

Sustainability

Social-ecological systems framework

Complexity

Holistic and systemic thinking

\begin{abstract}
A B S T R A C T
The aspiration to establish an effective dialogue between science and society has inspired some ground breaking examples of transdisciplinarity (TD). The core idea of TD is that different academic disciplines work jointly with practitioners to solve common problems. The first step of TD implies a contextualization that requires holistic and systemic thinking. To achieve this contextualization, we applied the Social -Ecological Systems (SES) framework with the aim of developing TD to deal with the recorded decline in area and tree density of the montado land-use system located in the Alentejo region, Portugal. The study was based both on a literature review and on the analysis of qualitative and quantitative data collected in a number of research projects on the montado. The results show that the lack of consensus regarding the system boundaries, the diverse range of mental models, and the disconnection between policymaking and system singularities are some of the conditions that can hinder TD efforts. The framework allowed the identification of knowledge gaps that limit the understanding of the problem complexity to be dealt with by a TD research process. There is a need to gain a better understanding of the governance system, and to characterize the different types of agro-silvo-pastoral combinations that can be designated as montado. With this detailed understanding, a tailored TD process can be designed. This work argues for the active use of the SES framework in TD in environmental management. Future research could focus on the framework's utility in developing tools to assess and monitor transdisciplinary research.
\end{abstract}

() 2018 Elsevier Ltd. All rights reserved.

\section{Introduction}

At the core of sustainability challenges lies the problem of managing complex social-ecological systems under both uncertainty and a plurality of values and perspectives (Gaziulusoy and Boyle, 2013; Williams et al., 2017). Viewing a sustainability problem from a specific disciplinary perspective is important, and so is the need to connect knowledge from different disciplines and beyond them (Hadorn et al., 2008; Williams et al., 2017).

\footnotetext{
* Corresponding author.

E-mail addresses: mhguimaraes@uevora.pt (M.H. Guimarães),nunogui@uevora. pt (N. Guiomar), dj@uevora.pt (D. Surová), sgodinho@uevora.pt (S. Godinho) mtpc@uevora.pt (T. Pinto Correia), Audun.Sandberg@nord.no (A. Sandberg), federica.ravera@uvic.cat (F. Ravera), marta@iseg.ulisboa.pt (M. Varanda).
}

Environmental issues exemplify complexity and require the production of system-based knowledge instead of generalist, decontextualized and reductionist knowledge (Seifferta and Loch, 2005; Lang et al., 2012). Problem-focused and contextualized research is seen, by many knowledge analysts, as being incompatible with the disciplinary framing of research problems and the institutional structures and processes that support, regulate, and promote disciplinarity (Russell et al., 2008; Gaziulusoy and Boyle, 2013). A supplementary approach that is advanced as an appropriate response to the shifting mandate faced by university-based researchers is transdisciplinarity (TD) (Gaziulusoy and Boyle, 2013; Manring, 2014). The definition of TD is not completely consensual in the literature (Pohl, 2011). In this article, we use the core idea of TD as expressed by Klein et al. (2001), consisting of different academic disciplines working jointly with practitioners (i.e., non- 
academic actors) to solve a real-world problem. In more detail, and as suggested by Pohl (2011), transdisciplinary research can be defined as "research that frames, analyses, and processes an issue such as: (1) the issue's complexity is grasped; (2) the diverse perspectives on the issue are taken into account; (3) abstract and casespecific knowledge are linked; and (4) descriptive, normative, and practical knowledge is produced and promotes what is perceived to be the common good. Representatives of different disciplines, of the private and the public sectors, and of the civil society, coproduce knowledge on an issue, trying to match (1) to (4)."

Carew and Wickson (2010) argue that recognizing and accounting for context is a necessary precondition for designing and executing high-quality transdisciplinary research because of the multiple constraints and opportunities implicit within a rich context. Understanding this rich context needs to be achieved by tools that allow not only the identification of its components but how they are interlinked forming a complex structure (Seifferta and Loch, 2005; Gaziulusoy and Boyle, 2013; Williams et al., 2017). In searching for ways of grasping an issue's complexity and context, we have found the Social-Ecological Systems (SES) framework (Ostrom, 2009). The overview and comparison of the available frameworks for analysing social-ecological systems by Binder et al. (2013) concludes that no framework can be used for all purposes. We selected the SES framework because it offers an interdisciplinary tool that allows different degrees of specificity considered needed to grasp the complexity of both social and ecological systems and their interactions (Binder et al., 2013; Manring, 2014; Vogt et al., 2015). By the identification of the different subsystems and the interaction between them, the SES framework is helpful tool for holistic and systemic thinking about complexity since it helps organize and connect previously isolated knowledge (Seifferta and Loch, 2005; Ostrom, 2009; Gaziulusoy and Boyle, 2013). The application of the SES framework in a contextualization process of transdisciplinary research can be considered an extended application of Ostrom's work. As Ostrom (2009) clarifies, the SES framework was built as a platform to organize and accumulate knowledge derived from different scientific areas that normally develop knowledge in an independent way and which are not readily combined.

In relation to the definition of TD used here (Klein et al., 2001; Pohl, 2011) our hypothesis is that the SES framework can help in a preliminary contextualization for promoting TD. Although the quantity of tools available to develop transdisciplinary research are increasing (e.g. Td-net's toolbox, Tools for integration \& Implementation Sciences) there is still a lack of clarity about the tools that allow TD promoters to reflect on and plan such research process (Gaziulusoy and Boyle, 2013). Understanding the complexity of the problem to be dealt with by TD is the first challenge (Seifferta and Loch, 2005; Manring, 2014; Gaziulusoy and Boyle, 2013). The promoters of TD are too often anchored in a specific disciplinary identity, looking at the problem from a thought-style, specific perspective or subsystem only (Pohl, 2011). Therefore, they lack a holistic view of the system under analysis and a view of the existing knowledge and related gaps (Seifferta and Loch, 2005; Gaziulusoy and Boyle, 2013). Consequently, our aim is to make use of the SES framework to attain a holistic view of a sustainability problem. The goal is to demonstrate how the SES framework can be used as a TD tool, specifically for unravelling the challenge of sustainability in a complex system.

To achieve this goal we apply the SES framework in an empirical case study focused on the decline of the montado land-use system of the Alentejo region in Portugal. At European level, these agrosilvo-pastoral systems are considered paradigmatic High Nature Value farmlands (HNV; Almeida et al., 2013). As HNV farming systems, montados are seen as low intensity land use systems, requiring low-energy inputs and low chemical treatments and comprising high levels of biodiversity (Bugalho et al., 2011). In addition, and due to their intrinsic nature as multi-functional landscapes, montados are key assets for enhancing rural sustainability and resilience (Pinto-Correia et al., 2011). Despite of the acknowledgement of the multiple values and services that are provided by these systems, their long-term sustainability is threatened (Godinho et al., 2016a). Due to its high structural and functional complexity, recent dynamics and conflicting values, the montado case study encompasses multiple economic, ecological and governance challenges.

We start by presenting a literature review regarding the use of the SES framework to analyse complex sustainability issues. Later we apply the framework to the empirical study by combining a second literature review focussed on the montado. The characterization of the framework variables in our particular case is later compared with the characterization achieved by the first literature review. The results of this comparative exercise is discussed in light of its utility in a contextualization process of TD. The main contributions of this work can be summarized as (a) it offers a holistic approach to problem framing and TD planning; (b) it identifies the key aspects that can influence collective actions such as TD and (c) provides a characterization of the social and ecological interconnections of the sustainability problems in the case of the montado that, to the best of our knowledge, have not yet been reported.

\section{Reviewing the use of the SES framework in environmental management}

The SES framework is a general framework for analysing the sustainability of SES that provides a methodology to systematically unpack first-tier core subsystems in terms of the second-tier and, if needed, third-tier variables (Ostrom, 2009; McGinnis and Ostrom, 2014). Fig. 1 represents the most recent configuration of the firsttier core subsystems of the SES framework (detailed in McGinnis and Ostrom, 2014). A comprehensive description of the variables currently listed in the second-tier can be found in McGinnis and Ostrom (2014).

The literature review summarized in Table 1 started with a search in Science Direct database using the keywords: "socialecological framework*" and "sustainability*". From this first query, we retrieved 40 scientific articles. This initial number was reduced to 11 by selecting the studies dealing with sustainability issues in environmental management and which included the characterization of at least one of the second-tier variables of the SES

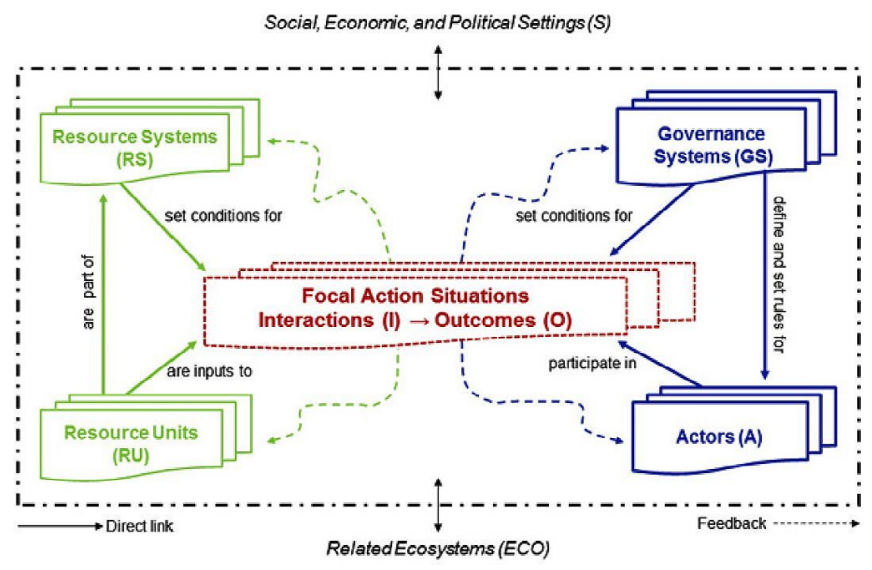

Fig. 1. Revised social-ecological systems (SES) framework with multiple first-tier components. Source: McGinnis \& Ostrom (2014). 
Table 1

A review of the second-tier variables of importance for analysing the sustainability of social-ecological systems, and a summary of the main interactions studied.

\begin{tabular}{|c|c|c|c|}
\hline Subsystems & $\begin{array}{l}\text { Second-tier } \\
\text { variables }\end{array}$ & Interactions studied & Studies \\
\hline \multirow{5}{*}{$\begin{array}{l}\text { Resource } \\
\quad \text { Systems } \\
\text { (RS) }\end{array}$} & $\begin{array}{l}\text { Clarity of system } \\
\text { boundaries (RS2) }\end{array}$ & $\begin{array}{l}\text { Undefined boundaries complicate the definition of rules, and conflicts } \\
\text { might escalate. }\end{array}$ & $\begin{array}{l}\text { Agrawal 2001; Fleischman et al., 2010; Bennett and Gosnell } \\
2015\end{array}$ \\
\hline & $\begin{array}{l}\text { Size of resource } \\
\text { system (RS3) }\end{array}$ & $\begin{array}{l}\text { A moderate size is conducive to self-organization; a large size means } \\
\text { higher management costs; a smaller size may imply a less valuable flow of } \\
\text { products from the system. }\end{array}$ & $\begin{array}{l}\text { Agrawal 2001; Ostrom 2009; Fleischman et al., 2010; } \\
\text { Amblard 2012; Nagendra and Ostrom } 2014\end{array}$ \\
\hline & $\begin{array}{l}\text { Productivity of the } \\
\text { system (RS5) }\end{array}$ & A moderate level of resource scarcity is likely to induce collective action. & Ostrom 2009; Amblard 2012 \\
\hline & $\begin{array}{l}\text { Equilibrium of the } \\
\text { system (RS6) }\end{array}$ & $\begin{array}{l}\text { Understanding the equilibrium of the system is important to target } \\
\text { actions and advocate for the system's future utility. }\end{array}$ & Baur and Binder 2013; Bennett and Gosnell 2015 \\
\hline & $\begin{array}{l}\text { Predictability of the } \\
\text { system (RS7) }\end{array}$ & $\begin{array}{l}\text { Low predictability implies higher management costs that may decrease } \\
\text { the incentives for action. }\end{array}$ & Amblard 2012; Bennett and Gosnell 2015 \\
\hline \multirow[t]{3}{*}{$\begin{array}{l}\text { Resource } \\
\text { Units } \\
\text { (RU) }\end{array}$} & $\begin{array}{l}\text { Resource unit } \\
\text { mobility (RU1) }\end{array}$ & $\begin{array}{l}\text { Mobile units are characterized by the high costs of observing and } \\
\text { managing a system. In grazing systems, marginal areas might appear } \\
\text { owing to the lower mobility of some types of cattle. }\end{array}$ & Amblard 2012; Baur and Binder 2013; Risvoll et al., 2014 \\
\hline & $\begin{array}{l}\text { Economic value } \\
\text { (RU4) }\end{array}$ & $\begin{array}{l}\text { Higher values may diminish the cost of actions and increase the } \\
\text { willingness to engage in collective actions. }\end{array}$ & $\begin{array}{l}\text { Fleischman et al., 2010; Baur and Binder 2013; Bennett and } \\
\text { Gosnell } 2015\end{array}$ \\
\hline & $\begin{array}{l}\text { Spatial/temporal } \\
\text { distribution (RU7) }\end{array}$ & Detecting changes through space and time is needed to promote actions. & $\begin{array}{l}\text { Baur and Binder 2013; Bennett and Gosnell 2015; Guerrero } \\
\text { and Wilson, } 2017\end{array}$ \\
\hline \multirow{6}{*}{$\begin{array}{l}\text { Governance } \\
\text { Systems } \\
\text { (GS) }\end{array}$} & $\begin{array}{l}\text { Governmental } \\
\text { organizations (GS1) }\end{array}$ & $\begin{array}{l}\text { The congruency of established rules with local conditions favours the } \\
\text { achievement of long-term sustainability. }\end{array}$ & $\begin{array}{l}\text { Ostrom 2009; Amblard 2012; Nagendra and Ostrom 2014; } \\
\text { Risvoll et al., 2014: Guerrero and Wilson, } 2017\end{array}$ \\
\hline & $\begin{array}{l}\text { Nongovernmental } \\
\text { organizations (GS2) }\end{array}$ & $\begin{array}{l}\text { The existence and activity of nongovernmental organizations might } \\
\text { induce or hamper the capacities of collective actions. }\end{array}$ & $\begin{array}{l}\text { Ostrom 2009; Amblard 2012; Nagendra and Ostrom 2014; } \\
\text { Bennett and Gosnell 2015; Guerrero and Wilson, } 2017\end{array}$ \\
\hline & $\begin{array}{l}\text { Property rights } \\
\text { systems (GS4) }\end{array}$ & $\begin{array}{l}\text { There is a variety of property rights that in a specific context might help or } \\
\text { hamper actions. }\end{array}$ & $\begin{array}{l}\text { Ostrom 2009; Fleischman et al., 2010; Baur and Binder } \\
\text { 2013; Bennett and Gosnell } 2015\end{array}$ \\
\hline & $\begin{array}{l}\text { Operational rules } \\
\text { (GS5) }\end{array}$ & $\begin{array}{l}\text { The autonomy that users have to define and enforce the rules for } \\
\text { governing resources has been found to be crucial in successful collective }\end{array}$ & $\begin{array}{l}\text { Agrawal 2001; Ostrom 2009; Fleischman et al., 2010; } \\
\text { Amblard 2012; Baur and Binder 2013; Nagendra and }\end{array}$ \\
\hline & $\begin{array}{l}\text { Collective-choice } \\
\text { rules (GS6) } \\
\text { Constitutional rules } \\
\text { (GS7) }\end{array}$ & actions. & Ostrom 2014; Risvoll et al., 2014; Bennett and Gosnell 2015 \\
\hline & $\begin{array}{l}\text { Monitoring and } \\
\text { sanctioning rules } \\
\text { (GS8) }\end{array}$ & $\begin{array}{l}\text { The long-term sustainability of rules devised at a local level depends on } \\
\text { monitoring and enforcement that are not overruled by higher-level } \\
\text { government policies. }\end{array}$ & $\begin{array}{l}\text { Agrawal 2001; Ostrom 2009; Fleischman et al., 2010; } \\
\text { Amblard 2012; Baur and Binder 2013; Risvoll et al., 2014; } \\
\text { Bennett and Gosnell } 2015\end{array}$ \\
\hline \multirow[t]{8}{*}{ Actors $(A)$} & $\begin{array}{l}\text { Number of actors } \\
\text { (A1) }\end{array}$ & $\begin{array}{l}\text { The effect on self-organization depends on other variables and the types } \\
\text { of management tasks (e.g. monitoring task can profit from large number } \\
\text { of actors involved). }\end{array}$ & $\begin{array}{l}\text { Fleischman et al., 2010; Ostrom 2009; Gutiérrez et al., 2011; } \\
\text { Amblard 2012; Nagendra and Ostrom 2014; Risvoll et al., } \\
\text { 2014; Guerrero and Wilson, } 2017\end{array}$ \\
\hline & $\begin{array}{l}\text { Socioeconomic } \\
\text { attributes (A2) }\end{array}$ & $\begin{array}{l}\text { Understanding such attributes through time is important to track } \\
\text { socioeconomic changes and also the inclusion and exclusion of particular } \\
\text { groups. }\end{array}$ & $\begin{array}{l}\text { Baur and Binder 2013; Nagendra and Ostrom 2014; Bennett } \\
\text { and Gosnell } 2015\end{array}$ \\
\hline & History of use (A3) & $\begin{array}{l}\text { What has happened in the past can impact the desirability and feasibility } \\
\text { of changes. }\end{array}$ & Fleischman et al., 2010; Risvoll et al., 2014; Petty et al., 2015 \\
\hline & Location (A4) & Location impacts the capacity and arrangement of actions. & $\begin{array}{l}\text { Baur and Binder 2013; Bennett and Gosnell 2015; Guerrero } \\
\text { and Wilson, } 2017\end{array}$ \\
\hline & $\begin{array}{l}\text { Leadership/ } \\
\text { entrepreneurship } \\
\text { (A5) }\end{array}$ & $\begin{array}{l}\text { When some actors have entrepreneurial skills and are respected as } \\
\text { leaders, self-organization is more likely. }\end{array}$ & $\begin{array}{l}\text { Ostrom 2009; Gutiérrez et al., 2011; Amblard 2012; } \\
\text { Nagendra and Ostrom 2014; Bennett and Gosnell 2015 }\end{array}$ \\
\hline & $\begin{array}{l}\text { Norms (trust } \\
\text {-reciprocity) and } \\
\text { social capital (A6) }\end{array}$ & $\begin{array}{l}\text { Shared moral and ethical standards, as well as the existence of reciprocity } \\
\text { norms and trust, will mean lower costs in forming agreement and in } \\
\text { stabilising monitoring activities. }\end{array}$ & $\begin{array}{l}\text { Agrawal 2001; Ostrom 2009; Fleischman et al., 2010; } \\
\text { Gutiérrez et al., 2011; Amblard 2012; Nagendra and Ostrom } \\
\text { 2014; Bennett and Gosnell 2015; Guerrero and Wilson, } \\
2017\end{array}$ \\
\hline & $\begin{array}{l}\text { Knowledge of SES } \\
\text { and mental models } \\
\text { (A7) }\end{array}$ & $\begin{array}{l}\text { The existence of shared mental models implies a level of cohesion, } \\
\text { whereas distinct mental models have been linked with conflict situations. }\end{array}$ & $\begin{array}{l}\text { Fleischman et al., 2010; Amblard 2012; Risvoll et al., 2014; } \\
\text { Bennett and Gosnell 2015 }\end{array}$ \\
\hline & $\begin{array}{l}\text { Importance of } \\
\text { resource } \\
\text { (dependence) (A8) }\end{array}$ & $\begin{array}{l}\text { The greater the importance of the resource to actors' livelihoods, or the } \\
\text { higher the value attached to the sustainability of the resource, the greater } \\
\text { the success of self-organization. }\end{array}$ & $\begin{array}{l}\text { Agrawal 2001; Ostrom 2009; Amblard 2012; Baur and } \\
\text { Binder 2013; Nagendra and Ostrom } 2014\end{array}$ \\
\hline \multirow[t]{4}{*}{$\begin{array}{l}\text { Interactions } \\
\text { (I) }\end{array}$} & $\begin{array}{l}\text { Information sharing } \\
\text { (I2) }\end{array}$ & $\begin{array}{l}\text { Sources of transaction costs include asymmetrical information (or lack of } \\
\text { information sharing). }\end{array}$ & $\begin{array}{l}\text { Fleischman et al., 2010; Amblard 2012; Baur and Binder } \\
\text { 2013; Risvoll et al., 2014; Bennett and Gosnell 2015; Petty } \\
\text { et al., 2015; Guerrero and Wilson, } 2017\end{array}$ \\
\hline & $\begin{array}{l}\text { Deliberation } \\
\text { processes (I3) }\end{array}$ & $\begin{array}{l}\text { Details need to be understood because the simple existence of } \\
\text { deliberation processes might not be synonymous with common } \\
\text { understandings and self-organization. }\end{array}$ & $\begin{array}{l}\text { Agrawal 2001; Nagendra and Ostrom 2014; Risvoll et al., } \\
\text { 2014; Bennett and Gosnell } 2015\end{array}$ \\
\hline & Conflicts (I4) & $\begin{array}{l}\text { Understanding conflicts and making them explicit can promote self- } \\
\text { organizational capacity. Changes can make some conflicts disappear } \\
\text { while others appear. }\end{array}$ & $\begin{array}{l}\text { Fleischman et al., 2010; Amblard 2012; Nagendra and } \\
\text { Ostrom 2014; Risvoll et al., } 2014\end{array}$ \\
\hline & $\begin{array}{l}\text { Networking } \\
\text { activities (I8) }\end{array}$ & $\begin{array}{l}\text { The existence of networks (e.g., government and users) can contribute to } \\
\text { collective actions. }\end{array}$ & $\begin{array}{l}\text { Fleischman et al., 2010; Amblard 2012; Nagendra and } \\
\text { Ostrom 2014; Guerrero and Wilson, } 2017\end{array}$ \\
\hline
\end{tabular}


framework. Table 1 summarizes the results of the review by listing the subsystem and respective second-tier variables, providing a short description of the characterization achieved and the references used. The characterization presented in the third column of Table 1 is mostly focus on the impact that a general status of each second-tier variable can have in the success of collective actions towards sustainability. Based on the definition of TD used here, our focus in collective actions is explained by the fact that for TD to happen, actors need to actively engage in the process. Therefore, understanding how the context can affect this decision is a necessary step for those promoting a TD research process. In this review, we have not analysed variables measuring the outcomes or the external settings or drivers (ECO) influencing the whole system, as our main goal is the internal characterization of the system.

From the review undertaken, and to the best of our knowledge, no previous study has explicitly engaged the SES framework in a practical transdisciplinary research process. Neither have we found any study that attempts the detailed characterization of second-tier variables prescribed by McGinnis and Ostrom (2014).

With regard to subsystem designated as the Resource Systems (RS) we found that the clarity of the system boundary (RS2) can impact the establishment and enforcement of rules. Thus, unclear boundaries can in turn promote conflicts among actors (Table 1). Extremely large systems (RS3) will be harder to manage due to higher management costs. If a certain level of scarcity is not actually observed, actors will not see the need to change future management actions (RS5). Considering the system equilibrium (RS6) status, a significant move away from it might induce collective actions. However, this needs to occur within the limits of reversibility, which can be understood only if there is a certain level of predictability of the system dynamics (RS7). With regard to the Resource Units subsystem (RS) a relevant finding was that resource units with low mobility (RU1) can imply distinctive pressure in the system (e.g., grazing animals will tend to concentrate in specific areas). Hence, the spatial and temporal distributions of resource units (RU7) are important features to consider when defining management actions. Most studies also found that the higher the economic value of the resource units (RU4), the greater is the willingness to engage in collective actions.

McGinnis and Ostrom (2014) explain the Governance Systems (GS) as the set of conditions and rules used in a particular action situation. The studies consulted show that long-term sustainability has been recorded when the established rules are congruent with local conditions (GS5-8, Table 1). Further, the autonomy that users have to define and enforce the rules governing resource management can be vital to long-term sustainability. Although it is important to identify the governmental organizations (GS1) involved in a specific issue, the existence and activity of nongovernmental organizations (GS2) can also be essential to the achievement of sustainability. Most studies argue that property rights as rules (GS5) can have important impacts in collective actions, but they are usually historically evolved rather than purposely designed. Thus they tend to be "sticky" and difficult to change.

In the Actors (A) subsystem, most studies conclude that the impact of the quantity of actors (A1) depends on other variables as well as on the management tasks defined (Table 1). A high number of actors might hinder self-organization because of the costs of getting them together and agreeing on changes, whereas in other cases a critical mass is required to mobilize the resources needed. The locations of the different actors (A4) can impact the capacity and possible arrangements of collective actions. Socioeconomic attributes (A2) can influence self-organization through, for example, the inclusion or exclusion of certain groups. The history of use (A3) is often described owing to its importance in explaining complex ecological and social phenomena. The existence of actors that are recognized within the system as leaders or as having entrepreneurship capacities (A5) facilitates collective actions. Shared and cohesive knowledge about the SES (A7) also positively influences self-organization, whereas the lack of such is frequently linked with conflicts that block such attempts. Users who share moral standards (A6) and who have sufficient trust in one another to keep agreements face lower transaction costs in reaching agreements as well as monitoring adherence to these. In cases of successful collective actions, it is typical that there is a highperceived dependence on the resource system (A8) for local livelihoods or a high value attached to its continued productivity.

Within the Interactions (I) in Action Situations (see Table 1), the lack of (or asymmetric) information sharing was found to increase transaction costs (I2). The existence of good deliberation processes (I3) can contribute to decrease these costs by improving the level of communication and information sharing. However, the content of these processes and the way in which they work need to be understood, as uneven power relations may continue to occur even when deliberation exists. The higher the levels of conflict (I4), the lower the capacity for self-organization. Finally, the existence of networking activities (I8) can be a favourable precondition for successful collective actions.

\section{The SES framework application to the case study}

The case study used in the montado agro-silvo-pastoral system (corresponding to dehesa in Spain) that covers a large part of the Alentejo region in southern Portugal (Fig. 2). Cork and holm oaks (Quercus suber and Quercus [ilex] rotundifolia, respectively) are the dominant tree species and have varying densities commonly combined with livestock grazing or annual crops in the herbaceous layer (Godinho et al., 2016a).

Of the $56 \mathrm{~s}$-tier variables described in McGinnis and Ostrom (2014), we selected and characterized 30 variables for our case study. The variables selection took into consideration the variables identified in the literature review (Table 1) and the specificities of the case-study. Therefore, we added 3 other variables that were not found in the literature review: location (RS9), interaction between resource units (RU3) and network structure (GS3).

Each variable was characterized by mobilizing and combining the knowledge derived from several sources. A literature review in Science Direct database was done using the keywords "montado*" and "Alentejo*". This first search resulted in the identification of 78 articles from which 20 were excluded because of lack of institutional access. From the 58 article gathered we selected 16 for the characterization of the second-tier variables of the SES framework. Some information could be retrieved in several articles and we referred those useful for the characterization of several variables. Other sources of information such as newspaper articles, websites, blogs, and policy briefs were usefull to complement the caracterization of some variables. Primary data (see details in Table 2) was also used and obtained from geographical information systems, surveys (e.g., questionnaires and interviews), and participatory methodologies (e.g., focus groups, workshops). These data was analysed by content and spatial analyses.

\section{Results}

Below, we present a characterization of the results for the 30 selected second-tier variables of the SES framework (Tables 3 and 4 and Fig. 3). The results are presented in three subsections. ${ }^{1}$

\footnotetext{
${ }^{1}$ References and data sources are reported in Tables 3 and 4 and Fig. 3.
} 

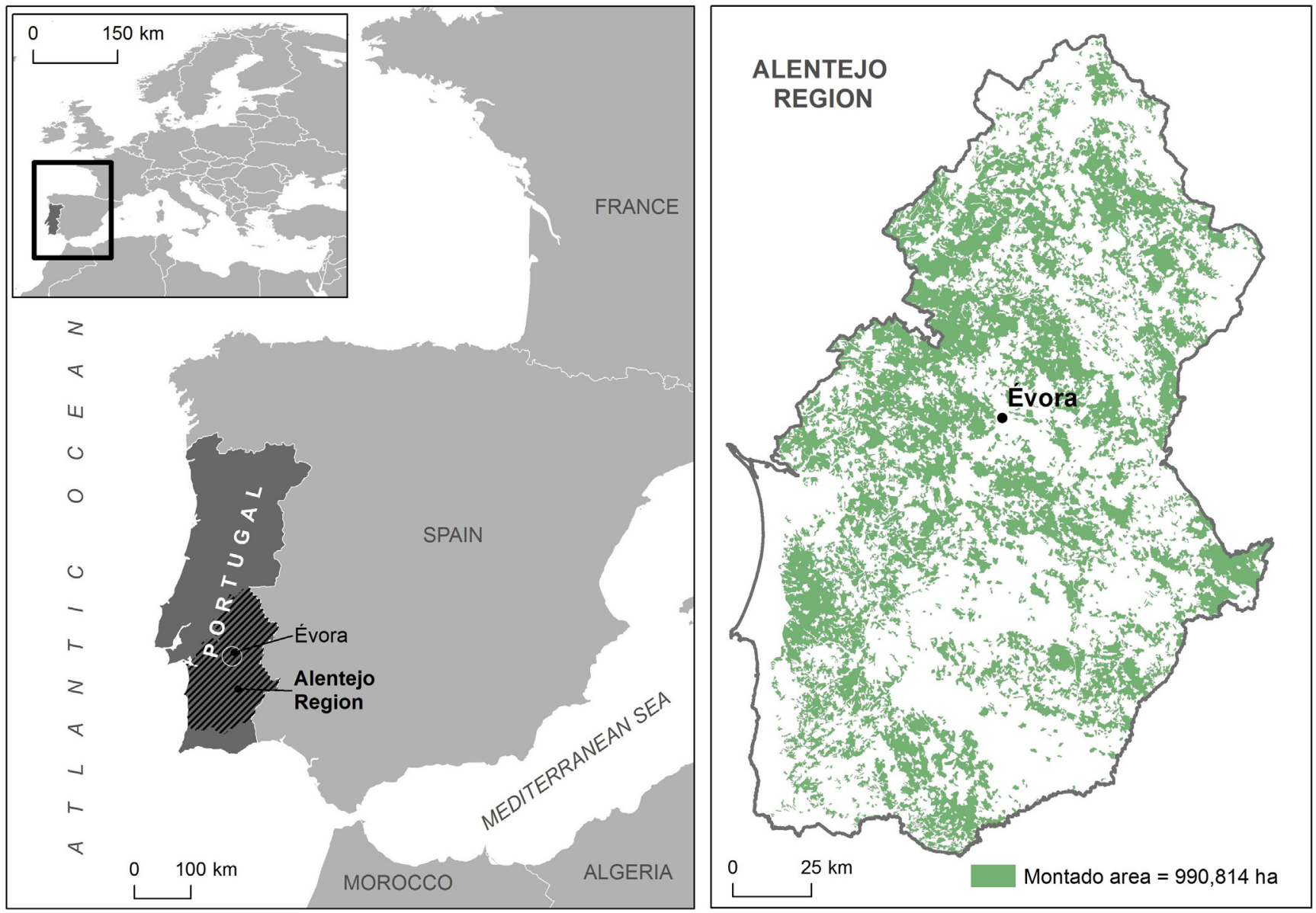

Fig. 2. The location and coverage of the montado in the Alentejo region (2006 data) (source: Godinho et al., 2016b).

\subsection{Resource units and resource system}

The montado resource system (Table 3 ) is composed of several units, including the soil, trees, wildlife, game, livestock, shrubs, herbs, and acorns. The system is exploited for cork, charcoal, game, honey, mushrooms, meat, dairy products, and tourism (RU4). Therefore, the system includes both fixed units (RU1) and mobile resources. The mobility of livestock is usually controlled by fences within a property. The complexity of the management of the montado is related to the high levels of interaction between its

Table 2

Details regarding the data used in the application of the SES framework in the specific case study.

\begin{tabular}{|c|c|c|c|}
\hline $\begin{array}{l}\text { Methodology/ } \\
\text { technique }\end{array}$ & $\begin{array}{l}\text { Number of } \\
\text { participants }\end{array}$ & Participants by thematic groups & Project and data source \\
\hline Interviews & 30 & $\begin{array}{l}\text { (1) 'Run the Land', including those who manage agriculture at the } \\
\text { farm level (farmers and estate managers); (2) 'Young Farmers' } \\
\text { (those under } 40 \text { years); (3) 'Benefit from the Land', comprising }\end{array}$ & $\begin{array}{l}\text { Semi-structures interviews developed under the European project } \\
\text { FarmPath in 2013, details can be consulted in Pinto-Correia et al., } \\
\text { (2011) and McKee et al., } 2015\end{array}$ \\
\hline Focus groups & $\begin{array}{l}4 \text { session } \\
\text { involving a total } \\
\text { of } 32 \\
\text { participants }\end{array}$ & $\begin{array}{l}\text { those who use rural land for other activities and who represent } \\
\text { rural community interests; (4) those who are responsible for } \\
\text { decision-making and the management of agriculture and land- } \\
\text { based activities at the regional level (so-called 'Official Interests'). }\end{array}$ & $\begin{array}{l}\text { Focus groups discussion led by a skilled facilitator in } 2013 \text { under } \\
\text { the European project FarmPath in 2013, details can be consulted in } \\
\text { Pinto-Correia et al., (2011) and McKee et al., } 2015\end{array}$ \\
\hline Workshops & 27 & & $\begin{array}{l}\text { Workshop designed to facilitate interaction between stakeholders } \\
\text { and researchers. During the workshop, participants discussed } \\
\text { visions for the future and co-produced pathways to reach the } \\
\text { desired visions. Workshop occurred in } 2013 \text { under the European } \\
\text { project FarmPath in 2013, details can be consulted in Pinto-Correia } \\
\text { et al., (2011) and McKee et al., } 2015\end{array}$ \\
\hline Questionnaires & 232 & $\begin{array}{l}\text { workers }(\mathrm{N}=26) \text {, hunters }(\mathrm{N}=26) \text {, beekeepers }(\mathrm{N}=29) \text {, } \\
\text { mushroom pickers }(\mathrm{N}=12) \text {, foreign tourists }(\mathrm{N}=24) \text {, new rural } \\
\text { inhabitants }(\mathrm{N}=31) \text {, rural inhabitants }(\mathrm{N}=28) \text {, urban dwellers } \\
\text { from Lisbon }(\mathrm{N}=28) \text { and landowners of the Montado of cork oak } \\
(\mathrm{N}=28)\end{array}$ & $\begin{array}{l}\text { Face-to face questionnaires were done between } 2005 \text { and } 2006 . \\
\text { Details can be consulted in Surová and Pinto-Correia (2008). }\end{array}$ \\
\hline $\begin{array}{l}\text { Spatial } \\
\text { analysis }\end{array}$ & - & - & $\begin{array}{l}\text { Census of Agriculture and land cover data from ICAAM spatial } \\
\text { analysis department }\end{array}$ \\
\hline
\end{tabular}


Table 3

Characterization of second-tier variables in the case study.

\begin{tabular}{|c|c|c|c|}
\hline $\begin{array}{l}\text { First-tier } \\
\text { variables }\end{array}$ & $\begin{array}{l}\text { Second-tier } \\
\text { variables }\end{array}$ & Details from the case study & Information source \\
\hline \multirow[t]{4}{*}{$\begin{array}{l}\text { Resource } \\
\quad \text { Systems } \\
\text { (RS) }\end{array}$} & $\begin{array}{l}\text { RS2: Clarity of } \\
\text { system boundaries } \\
\text { RS3: Size of } \\
\text { resource system }\end{array}$ & $\begin{array}{l}\text { Boundaries and size vary depending on the disciplinary perspective } \\
\text { as well as on actors' perspectives. }\end{array}$ & $\begin{array}{l}\text { Fragoso et al., 2011; Almeida et al., 2013; Pinto-Correia et al., 2013: } \\
\text { Pereira et al., 2015; Godinho et al., 2016b; workshops }\end{array}$ \\
\hline & $\begin{array}{l}\text { RS5: Productivity } \\
\text { of the system }\end{array}$ & $\begin{array}{l}\text { The goods and services provided by the montado include provision, } \\
\text { regulation, supporting, and cultural. }\end{array}$ & Ribeiro et al., 2010; Pinto-Correia et al., 2013; Sá-Sousa 2014 \\
\hline & $\begin{array}{l}\text { RS6: Equilibrium } \\
\text { of the system }\end{array}$ & $\begin{array}{l}\text { Most knowledge produced in research is about the management } \\
\text { actions that allow the system to be in equilibrium. }\end{array}$ & Ribeiro et al., 2010; Pinto-Correia et al., 2013 \\
\hline & $\begin{array}{l}\text { RS7: Predictability } \\
\text { of system } \\
\text { dynamics } \\
\text { RS9: Location }\end{array}$ & $\begin{array}{l}\text { The resource system is fixed, and many of the ecological processes } \\
\text { that occur have been described as predictable. The location of the } \\
\text { resource system is also identified. }\end{array}$ & Godinho et al., 2016b; Pinto-Correia et al., 2013 \\
\hline \multirow{4}{*}{$\begin{array}{l}\text { Resource } \\
\text { Units } \\
\text { (RU) }\end{array}$} & $\begin{array}{l}\text { RU1: Resource } \\
\text { unit mobility }\end{array}$ & $\begin{array}{l}\text { Trees are fixed whereas livestock have conditional mobility - } \\
\text { grazing activities can be controlled. }\end{array}$ & Ferraz-de-Oliveira et al., 2013; Pinto-Correia et al., 2013 \\
\hline & $\begin{array}{l}\text { RU3: Interaction } \\
\text { between resource } \\
\text { units }\end{array}$ & $\begin{array}{l}\text { High level of interaction. Management is needed to maintain the } \\
\text { system's balance. }\end{array}$ & $\begin{array}{l}\text { Pereira and Fonseca 2003; Ribeiro et al., 2010; Pinto-Correia et al., } \\
\text { 2011; Ferraz-de-Oliveira et al., } 2013\end{array}$ \\
\hline & $\begin{array}{l}\text { RU4: Economic } \\
\text { value }\end{array}$ & $\begin{array}{l}\text { The value depends on the type of montado, but it is linked with the } \\
\text { exploitation of cork, charcoal, game, honey, meat, dairy products, } \\
\text { and tourism. }\end{array}$ & $\begin{array}{l}\text { Pereira and Fonseca 2003; Pinheiro et al., 2008; Fragoso et al., 2011; } \\
\text { Pinto-Correia et al., 2011; Ferraz-de-Oliveira et al., 2013; Mestre } \\
\text { and Vogtlander, } 2013\end{array}$ \\
\hline & $\begin{array}{l}\text { RU7: Spatial and } \\
\text { temporal } \\
\text { distribution }\end{array}$ & $\begin{array}{l}\text { Not all resource units are spatial characterized. The temporal } \\
\text { distribution of resource units ranges from short (e.g., annual crops) } \\
\text { to long time periods (e.g., cork). }\end{array}$ & $\begin{array}{l}\text { Ribeiro et al., 2010; Ferraz-de-Oliveira et al., 2013; Pinto-Correia } \\
\text { et al. } 2013\end{array}$ \\
\hline $\begin{array}{l}\text { Governance } \\
\text { Systems } \\
\text { (GS) }\end{array}$ & $\begin{array}{l}\text { GS1: } \\
\text { Governmental } \\
\text { organizations }\end{array}$ & Well identified (Table 4). & $\begin{array}{l}\text { Stakeholder identification developed in the several projects } \\
\text { referred to in Table } 2\end{array}$ \\
\hline
\end{tabular}

GS2:

Nongovernmental organizations GS3: Network structure GS4: Property rights regime

Existing between different actors but does not have a regional expression.

Mostly private ownership and latifundia structure. Some areas a rented, with others implying an informal arrangement between landowners and land managers. The right to access might not be restricted to the landowner or land manager depending on the existence of public paths or fences. Some properties remain open to all by the option of the landowner. Users may have the right to harvest some goods provided by the montado (e.g., mushrooms).

GS5: Operational- No previous work describes the rules in use in the montado system. Surveys; interviews; workshops; Pinheiro et al., 2008; Bugalho choice rules However, there are manuals of good practice that explain the most suitable practices in the montado.

GS6: Collective- National law: Lei de Bases da Política Florestal, Lei 29/96, Decretochoice rules

GS7: lei 169/2001, and Decreto-lei n $155 / 2004$.

Included in Annex I of the European Union Habitats Directive (92/ 43/CEE), Common Agricultural Policy.

constitution

choice rules GS8: Monitoring and sanctioning rules

Actors (A) A1: Number of There is no exact number of actors that should be involved, but a relevant actors characterization is presented in Table 3.

Cork producers communicate their production to the authorities, but no other monitoring is officially performed. Regulations include sanctioning rules specific for management actions with impact on trees.

A2: Socioeconomic No characterization is made at the regional scale. attributes

A3: History or past Clearly identified and impacting on the existing management experiences arrangements currently identified.

A4: Location Long distances between actors.

A5: Leadership Herdade do Freixo do Meio; ICAAM; Tourism of the Alentejo.

and

entrepreneurship

A6: Norms (trust Not systematically identified but by the examples discovered it -reciprocity) and appears that the level of social capital is high.

social capital

A7: Knowledge of No cohesion (Figs. 5 and 6)

SES, mental

models

A8: Importance of The situation varies between landowners, some are full time land Surveys; workshops

resource

(dependence)

Interaction I2: Information

(I) sharing managers while others have other professional activities and the

montado is a side revenue. Several landowners have inherited properties.

There are limited instances where information sharing occurs mainly between land managers exploiting different resource units.
Surová and Pinto-Correia 2009; Barroso et al., 2013; Pinto-Correia et al., 2013; Schiller et al., 2014; McKee et al., 2015

Spatial analysis; Pinto-Correia and Godinho 2013; Sá-Sousa 2014 et al., 2011; Fragoso et al., 2011; Pinto-Correia and Godinho, 2013; Pinto-Correia et al., 2013; Sá-Sousa 2014; Godinho et al., 2016b

Decreto-lei 169/2001 and Decreto-lei n 155/2004

S 2008, 2009; Barroso et al., 2013; Pinto-Correia and Godinho 2013; Pinto-Correia et al., 2013; Sá-Sousa 2014; McKee et al., 2015 Cutileiro 1972; Amaral 1994; Pereira et al., 2015

Surveys; Cutileiro 1972; Amaral 1994

Surveys, website reviews; Schiller et al, 2014

Pinto-Correia et al., 2013; Schiller et al., 2014; McKee et al., 2015

Surveys; workshops; Surová and Pinto-Correia 2008; McKee et al. 2015 
Table 3 (continued)

\begin{tabular}{|c|c|c|c|}
\hline $\begin{array}{l}\text { First-tier } \\
\text { variables }\end{array}$ & $\begin{array}{l}\text { Second-tier } \\
\text { variables }\end{array}$ & Details from the case study & Information source \\
\hline & $\begin{array}{l}\text { I3: Deliberation } \\
\text { process } \\
\text { I4: Conflicts }\end{array}$ & $\begin{array}{l}\text { Because of the prevailing private property regime, the deliberation } \\
\text { process is not a collective action. } \\
\text { Not clearly identified but possibly existing between large- and } \\
\text { small-scale properties and between land managers and users. }\end{array}$ & $\begin{array}{l}\text { Pinheiro et al., 2008; Ribeiro et al., 2010; Barroso et al., 2013; Pinto- } \\
\text { Correia et al., 2013; McKee et al., 2015; Schiller et al., 2014; Godinho } \\
\text { et al., 2016b }\end{array}$ \\
\hline & $\begin{array}{l}\text { I8: Networking } \\
\text { activities }\end{array}$ & $\begin{array}{l}\text { Crie Montado, Tertúlias do Montado, LTER (Long Term Ecological } \\
\text { Research) Montado network. }\end{array}$ & \\
\hline
\end{tabular}

Table 4

Identification of actors and their characteristics.

\begin{tabular}{|c|c|c|c|}
\hline Actor & Position & Action & Control \\
\hline Landowners & Property rights; they own the land. & $\begin{array}{l}\text { Multifunctionality, extensification, } \\
\text { intensification, abandonment, delegation. }\end{array}$ & $\begin{array}{l}\text { The types of actions that they can undertake are } \\
\text { legally prescribed by regulations.* }\end{array}$ \\
\hline Land Managers & Rented/loaned & & $\begin{array}{l}\text { They also need to follow regulations* and can also } \\
\text { be controlled by the landowner. }\end{array}$ \\
\hline $\begin{array}{l}\text { Nongovernmental } \\
\text { organizations }\end{array}$ & $\begin{array}{l}\text { Local development, farmers' and producers' } \\
\text { associations, nature conservation. }\end{array}$ & $\begin{array}{l}\text { Some support land managers in developing } \\
\text { their activities. Others pressure farming } \\
\text { activities to maintain biodiversity. }\end{array}$ & $\begin{array}{l}\text { They have little control, yet they can support/ } \\
\text { promote collective actions. }\end{array}$ \\
\hline Researchers & $\begin{array}{l}\text { Disciplinary } \\
\text { Interdisciplinary } \\
\text { Transdisciplinary }\end{array}$ & $\begin{array}{l}\text { They can make and have made efforts to } \\
\text { highlight the current declining status of the } \\
\text { system and the management changes needed. }\end{array}$ & $\begin{array}{l}\text { No control over land management or } \\
\text { policymaking but have the capacity to influence } \\
\text { management/policy decisions. }\end{array}$ \\
\hline $\begin{array}{l}\text { Public } \\
\text { Administration }\end{array}$ & $\begin{array}{l}\text { Forestry and Nature Conservation Institute, } \\
\text { General Office for Agriculture and Rural } \\
\text { Development, Regional Office for Agriculture and } \\
\text { Fisheries, Regional Tourism Office, Commission of } \\
\text { Coordination and Regional Development, } \\
\text { municipalities }\end{array}$ & $\begin{array}{l}\text { They put into practice the policy guidelines } \\
\text { provided by policymakers. They are } \\
\text { intermediaries between landowners, land } \\
\text { managers, and policymakers. }\end{array}$ & $\begin{array}{l}\text { They can advise land managers regarding the best } \\
\text { practices and can make recommendations to } \\
\text { government regarding policy needs. They work } \\
\text { together with law-enforcement bodies to ensure } \\
\text { that regulations are being followed. }\end{array}$ \\
\hline $\begin{array}{l}\text { Law-enforcement } \\
\text { bodies }\end{array}$ & $\begin{array}{l}\text { Forest and nature conservation guards and } \\
\text { vigilantes, other law-enforcement bodies. }\end{array}$ & $\begin{array}{l}\text { They inspect whether regulations are being } \\
\text { followed. }\end{array}$ & $\begin{array}{l}\text { They can control the management actions of land } \\
\text { managers according to what is defined by law. }\end{array}$ \\
\hline Policymakers & $\begin{array}{l}\text { Ministry of Agriculture, Forestry, and Rural } \\
\text { Development }\end{array}$ & $\begin{array}{l}\text { Maintain the current system of policy by } \\
\text { activity or promote a policy package focused } \\
\text { on the montado. }\end{array}$ & $\begin{array}{l}\text { They have little control over the management } \\
\text { actions taken, but the way in which they organize } \\
\text { the Common Agricultural Policy has a strong } \\
\text { impact on the montado. }\end{array}$ \\
\hline Users & $\begin{array}{l}\text { Hunters } \\
\text { Beekeepers } \\
\text { Local people } \\
\text { Tourists } \\
\text { Artists } \\
\text { New entrants } \\
\text { Overall society }\end{array}$ & $\begin{array}{l}\text { Users engage in activities that can imply a } \\
\text { payment to the landowner and/or presence of } \\
\text { people on the land, which increases security. }\end{array}$ & They can influence management actions. \\
\hline
\end{tabular}

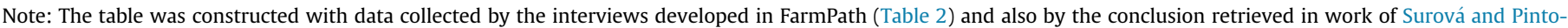
Correia (2008); Pinto-Correia et al., 2011; Barroso et al., 2013; Sá-Sousa 2014; Pereira et al., 2015.

resource units (RU3). A detailed description of the interactions between resource units can be found in the references in Table 3; here, we exemplify some of the interactions to explain the complexity in maintaining the health of the system. Although the predominance of oaks, as a major feature of the system, gives a sense of stability, in reality this is a dynamic system with a high spatial and temporal variability (RU7) that influences the equilibrium and productivity of the montado (RS5 and RS6). Short-term benefits, such as those resulting from the intensification of livestock, can negatively impact cork production, which is a medium-to long-term benefit. Shrubs may be used by game as shelter and by cattle as fodder, but these shrubs compete with trees for water and nutrients and also hamper the use of harvesters.

Although experts claim the need for further research to improve the predictability of the dynamics of the montado system, they have stated (in Pinto-Correia et al., 2013) that the current level of knowledge is sufficient to at least safeguard its conservation. Our definition of the location, size, and boundaries of the montado (RS2, 3 , and 9) follows the characterization provided by Godinho et al. (2016b) (Fig. 2), which indicated an area of around 1 million hectares in 2006. Those authors defined the system boundaries by considering a threshold canopy coverage of $10 \%$. Below $10 \%$ coverage, the trees are scattered to the extent that natural regeneration of the tree cover is severely limited, as the survival of young tree shoots depends strongly on the shadow and root interactions provided by the older trees. However, such delimitation is not consensual. Owing to the multifunctional capacity of the montado, and its structural diversity and spatial fuzziness, the definitions of the montado system are partly a function of the unit of interest (e.g., forestry, livestock, and farming). As an example, studies focusing on the economic viability of the montado (e.g., Fragoso et al., 2011) refer to the existence of about 2 million hectares, of which 1 million hectares is forest of Quercus[ilex] rotundifolia and Quercus suber. In such economic analyses, the agroforestry production systems includes other land uses such as olive groves, vineyards, and cereal systems.

\subsection{Actors and the system of governance}

One of the key issues in trying to characterize the actors involved in the sustainability of the montado is identifying who they are and how many they number (Tables 2 and 3). Most of the area covered by montado is under private land ownership, so landowners are key actors. To date, no study has been able to provide a reliable estimate of the number of landowners of the montado. Nevertheless, current knowledge allows us to identify the 


\begin{tabular}{|c|c|c|c|}
\hline $\begin{array}{c}\text { Trees } \\
\text { Fuel AMushroom } \\
\text { Forest Oak Pasture Herbs } \\
\text { Cattle Honey Cork Game } \\
\text { Wild Asparagus Gam } \\
\text { Landscape Shadow } \\
\text { Resources } \\
\text { Aromatic } \\
\text { Oxygen } \\
\text { Bees } \\
\text { Wood }\end{array}$ & $\begin{array}{c}\text { Balance } \\
\text { Tranquility } \\
\text { Sadness Peace Welcoming } \\
\text { FreedomPetion Time } \\
\text { Respect Extension Nostalgia } \\
\text { Serenity Quietness } \\
\text { Selanchaly } \\
\text { Sensations/Feelings } \\
\text { Comfortable } \\
\text { Hot } \\
\text { Soft } \\
\text { Harmony }\end{array}$ & $\begin{array}{c}\text { Alentejo } \\
\text { Adequate Eternity } \\
\text { Typical Continuity } \\
\text { Wisdom Generations Ours } \\
\text { Traddition Portugal Personal } \\
\text { Durability Characteristic } \\
\text { Memory Longevity Childhood Particular } \\
\text { Mediterranean } \\
\text { Heritage/Belonging } \\
\text { Permanency } \\
\text { Culture } \\
\text { Identity } \\
\text { Connection } \\
\text { old }\end{array}$ & \\
\hline \begin{tabular}{c}
\multicolumn{2}{c}{ Convivial } \\
Pleasant Useful \\
Vigorous Beauty See \\
Quality Marvellous Well \\
Special Important Fertility \\
Being Good Strength Mysterious \\
Appreciation \\
Magical \\
Life \\
Air \\
Pure \\
Needed
\end{tabular} & Loneliness & $\begin{array}{r}\text { Leis } \\
\text { vegetation Anir } \\
\text { Nappe Co } \\
\text { Contracts } \\
\text { Thinking sustainab. } \\
\text { wild Pic Land } \\
\text { Meditation Peasant B } \\
\text { Eleme } \\
\text { Rustic } \\
\text { Light } \\
\text { Big } \\
\text { Rast } \\
\text { Rest }\end{array}$ & 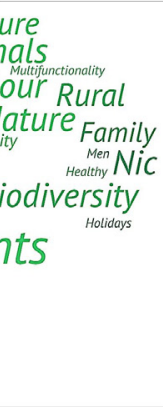 \\
\hline
\end{tabular}

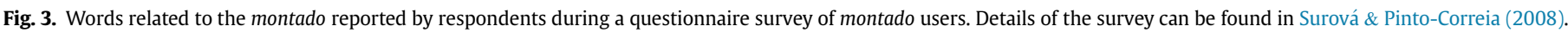
Note: The different size and colour of words do not have a particular meaning.

existence of 7589 farms with agroforestry areas in the Alentejo of which 5236 include the montado. The independent registration of these farms does not imply that they are managed individually. The existence of the historical latifundia structure (i.e., large farms owned by one individual, family, or company) suggests that a considerable number of these farms are managed by a single manager. Landowners are the ultimate decision-makers and can choose between multifunctionality, extensification, intensification, abandonment, or delegation of the management responsibility to others who have been appointed as land managers (Table 4). For some landowners, the montado can be their primary source of income, whereas for others it was once inherited and is considered a supplement to their main economic activity. It is also important to note that decision takers are conditioned by existing regulations, which, for example, protect the oak trees and constrain particular management activities such as pruning.

To the best of our knowledge, the number of land managers in the montado has not been quantified. Land managers (Table 4) may or may not be the landowners. Land managers take everyday decisions. When the landowner is not the land manager, the former is responsible for decisions that relate to the long-term, such as investments in infrastructures or planting new trees. Managing the montado implies a solid knowledge of its dynamics. However, land managers have reported the occurrence of sudden deaths and diseases of trees, as well as the inability to deal with such issues and the willingness to work with the research community to find solutions.

Researchers working with the montado are mainly doing independent knowledge creation and dissemination without direct control over the system. However, they have been actively advocating for the need to find solution that can sustain the montado system. Non-governmental organizations, mainly landowners and livestock-producer associations, provide technical support to land managers and can coordinate actions at a collective level, as they have direct contact with landowners and managers.

Public Administration is another key actor group (Table 4). Public administrators serve as intermediaries between land managers and policymakers and have the responsibility for accumulating detailed knowledge about the system. Without directly acting in the system, they put into practice policies that in turn should be influenced by their direct contact with land managers and landowners. They work in coordination with law-enforcement bodies that control management actions in accordance with the current regulation.

Policymaking (Table 4) is performed at the ministry (i.e., national) level, thus leaving little room for regional specifications. Several actions have been developed to increase awareness about the particularities of the montado at the policymaking level. Part of the sustainability problem currently faced has been linked to the transposition of the Common Agricultural Policy (CAP) to the national context. Therefore, although not directly involved in the management of the system, the impact capacity of policymaking is high.

Although the montado system is mainly privately owned and managed, there are still dimensions of the montado that are public, and in such situations, it can be considered a public good. ${ }^{2}$ In some situations, there are public walking paths that pass through private farms, which implies that landowners should allow--or at least tolerate--access. The demand of the public for access to the montado is increasing, particularly for activities such as bird watching, and recreational walking (Table 4). Such demand can force land managers and decision-makers to put into practice management actions that better safeguard the goods and services that the montado provides and devise rules that allow easier public access to the farms that make up this land-use system.

Socioeconomic attributes (A2) differ between actors, although such attributes have not been systematically analysed. Such differentiation is related to other variables such as the history of the system (A3). The Cereal Law (1889), the existence of a latifundia property structure, the wheat campaign of 1929-1949, the Agrarian Reform (1975-1979), the integration of Portugal into the

\footnotetext{
${ }^{2}$ Where the exclusion of users is infeasible or unacceptable and where the joint use of the good or the service is without problems (Ostrom, 1990).
} 
European Union (EU), and the 1992 revision of the CAP are historic milestones in the evolution of the montado. The latifundia farm structure, which is associated with a web of involved actors and influencing lobbyists, led to the continuation of a traditional use of the montado while cereal production led to extreme soil impoverishment and a decrease in the area of the montado. A key characteristic of the system is the large distance and low coherence between actors. The Alentejo is the country's largest region, and actors are spread throughout this region, with others (e.g., landowners, policymakers, and users) being located outside the region (A4).

At the regional level, we were not able to identify leaders (A5) promoting the maintenance of the montado, although several institutions, including the private sector, promote the value of the system (Table 4). There is no existing systematic overview of the norms and social capital operating in the montado, but there are indications of such social assets. For example, in the private sector, the Herdade do Freixo do Meio, undertakes several activities to promote the value of the montado, including the development of a network designated "Crie Montado". ICAAM has developed several initiatives that also include collaboration with Spanish actors involved in the same goal for the dehesas. In 2013, the "Green Book of the Montado" was developed and presented in the Portuguese parliament which resulted in a Resolution of the Assembly (dated 16 May 2014) calling for the attention of the Portuguese government to the book's conclusions. Finally, the Regional Office of Tourism of the Alentejo has submitted an application to UNESCO for the montado to be classified as a worldwide heritage area.

Other key variables are related to the absence of a cohesive mental model (A7) of the montado. The lack of a consensual understanding has been identified in several projects. In one of such project (FarmPath, see details in McKee et al., 2015) the montado was identified as a central element for regional development, although no consensus was reached regarding the activities that could lead to its future sustainability. Participants simultaneously wanted to enhance the system's sustainability and to intensify farming production and expand the area of irrigated crops. In the study conducted by Surová and Pinto-Correia (2008), different preferences for the montado landscapes were identified depending on the way in which the system is used. For instance, hunters prefer an open montado (i.e., low tree cover) whereas beekeepers favour dense montado (i.e., high tree cover) with scrub. Fig. 3 shows the diversity of the words that actors link to the term "montado". Around 150 words $^{3}$ were listed and categorized into the following groups: resources (i.e., provisioning and supply of regulating services), sensations and feeling (i.e., stimulus derived), heritage/ belonging (i.e., attributed cultural values), appreciation (i.e., quality recognition), disfavour (i.e., negative features), and a group of other words that did not fit the other categories.

An important component of the governance system is the "rules in use" (Table 3). At the operational level (GS5), we were not able to collect a full characterization of the practices involved, but several studies (see Table 3 ) have referred to damaging management practices (e.g., soil ploughing) and the alternative options (e.g., shrub-control techniques without soil mobilisation). Other studies have mapped land managers' aspirations in the montado, identifying distinct levels of concern and difficulties in balancing management practices that in the long run are able to protect the

\footnotetext{
${ }^{3}$ Words were collected in a face-to-face questionnaire survey conducted between 2005 and 2006 of 232 respondents who were included in one of the following categories: hunters, land-owners, mushroom pickers, beekeepers, rural inhabitants, workers in rural areas, urban dwellers, tourists, and new rural inhabitants. The categories were selected by the authors.
}

montado and still maintain short-term economic benefits.

Rules at the collective (GS6) and constitutional (GS7) level are closely related but are not always congruent with each other. The lack of communication between different levels of government and actors has been intensively discussed (see Table 3 ). Despite the various attempts to bring to the attention of policymakers the need for policy packages with correct incentives directly supporting the sustainability of the montado, no such policies have yet been formulated. The current regulations are fragmented, sometimes contradictory, and have a number of perverse effects. For instance, agro-environmental schemes were established under the previous CAP to promote environmentally friendly practices while discouraging intensification and/or land abandonment. However, these schemes have rarely been used in the montado; more short-term economic returns were achieved by the use of incentives for livestock production, which resulted in the deterioration of the montado as a result of overgrazing, erosion, and trees' vulnerability. The call for new design measures with multifunctional and environmental goals, seeking greater integration and more adherence to reality, is found among all actors listed in Table 4 except at the policymaking level.

\subsection{Interactions}

Information sharing (I2 in Table 3) currently occurs in an informal manner depending on individual initiatives. Multistakeholder networks have been described in multifunctional montado systems, implying a high level of coordination between actors. However, a trend towards single-function systems has also been reported.

Established conflicts (I4) between actors have not been detected despite the existence of several tensions. One such tension is related to the increased societal demand for the ecosystem services of the montado as a common good. Actors with a productivity perspective view the montado as part of a cultural heritage but not as compatible with current market demands. In this vision, certain areas of the montado should be kept, whereas others need to be converted to productive farming systems by intensification. At the another extreme are those actors trying to find ways of putting multifunctionality into practice as a way to respond to the current demands of the public while also ensuring economic profit.

By analysing environmental conditions (e.g., soil type and hydrological regime), the vulnerability of the agricultural economy (due to the changing incentive structure of successive EU CAPs), and changing labour force availability, we can explain the polarization of land use in the montado between land intensification on the one hand (e.g., higher grazing pressure, or modern permanentcrop farming systems) and land abandonment on the other hand (i.e., shrubland encroachment). Intensification leads to a lack of regeneration of trees and the consequent disappearance of the crown cover. Insufficient economic outcomes and an extreme reduction in levels of land care are indirectly the drivers of land abandonment. In the absence of human intervention, the montado vegetation will be overgrown by flammable native shrubs which in turn increase fire hazard and the loss of valuable habitat heterogeneity. Intensification and abandonment imply low to nonexistent collective actions whereas multifunctionality can occur only with high levels of collective action.

\section{Discussion}

In the montado case-study the inability to clearly identify who are the landowners and managers hinders the capacity of TD since the outreach of the initiatives cannot be related to the total population. Such situations exemplifiy Ostrom (1990) design principal 1: 
"individuals or households who have rights to withdraw resource units from the common pool resources (CPR) must be dearly defined, as must the boundaries of the CPR itself". A regional study to identify landowners and managers and to understand how management, at the operational-choice level, is occurring, could allow a more targeted TD research process.

Results show that the montado is not a homogenous land use system and there are different types of montado and corresponding business models, ranging from dense to open systems and from systems oriented to cork production to those focused on livestock production. A transdisciplinary research process would benefit from a clear characterization of the different types of montados. The challenges faced by a montado dedicated primarily to cork production are different from those faced by a montado focused mainly on hunting and/or livestock. This example shows the implications of different types of the montado for sustainability paths. With a clear typology of the montado, TD could then be a process tailored to each type.

Two of the most relevant second-tier variables characterized in this case-study were the system boundaries and the mental models. As other authors concluded, unclear system boundaries hinder collective actions towards improving the sustainability of natural resources (e.g., Ostrom, 1990, 2009; Fleischman et al., 2010). Unclear system boundaries in the montado case were found and, within a TD research process, this should be discussed between the participants. Only when clear system boundaries are defined can the economic viability of the montado be coherently addressed, a key motif for those owning and managing the land. As an example in Fragoso et al. (2011) shows, economic viability in the montado can be improved by investment in vineyards and olive groves, which, as argued by Godinho et al. (2016b), are not part of the original system. In fact, the search for space for these types of farming contributes to a decline in both the tree density and the extent of the montado. The existence of such disparities in how the limits of the montado are perceived not only hinders dialogue but can also have a significant impact on the sustainability of the system.

Adopting the SES framework, we were also able to understand enabling conditions and limitations that are essential for TD processes (Carew and Wickson, 2010). Ostrom (2009) shows that accumulated social capital and networking activities facilitate collective actions. Therefore, future transdisciplinary studies focused on the montado should benefit from former experiences. We also found that the capacity of TD in the montado case is challenged by the fact that the visual identification of decline occurs only when the ecological conditions are extremely degraded. This, in turn, implies that not all actors perceive the same system threats that make them willing to engage in transdisciplinary efforts. Not perceiving the risk hinders the change in behaviour that is needed (Ostrom, 2009; Amblard, 2012). Land managers' and landowners' involvement in the montado and their economic dependence varies, and this will also influence their engagement in TD. Actors with higher stakes and greater dependence on the montado for their livelihoods will probably engage in TD more readily than will those with other sources of income or those who are simply the passive heirs of the montado areas.

The economic trade-offs between different management activities is not a topic of most of the literature focused on the montado. However, the perception of these trade-offs appears to have a considerable influence on land managers' decisions. Further, there is a mismatch between landowners' paths towards single functional systems and the societal demand for access to a diversity of ecosystem services provided by the montado. As Risvoll et al. (2014) conclude, there is a need to match interests between different actors. In the case of the montado, this means that the multifunctional path needs to complement the agenda of economic development and should not be considered an opposing path (Pinto-Correia et al., 2013; Sá-Sousa, 2014). In itself, TD is an opportunity to develop interactions that can promote more multifunctionality in the montado, as face-to-face communication is paramount (Baur and Binder, 2013; Petty et al., 2015). In the montado the current property regimes (i.e., mostly private) and the disconnection observed between different landowners in relation to the expectations of other users is a big challenge. However, this could also be an opportunity for TD. Although the disconnection between actors can hamper their engagement in TD, the fact that TD is a meeting point between different actors can serve as an attractor to participation. The lack of articulation between different levels of governance is also a substantial difficulty currently facing the development of policy actions that could promote the sustainable management of the montado. The lack of networking activity between governmental institutions capable of defining incentives that could change individuals' behaviour towards sustainable ends hampers self-organization efforts (Ostrom, 2009; Gutiérrez et al., 2011; Amblard, 2012; Nagendra and Ostrom, 2014).

The distribution of the montado shown in Fig. 2 clearly demonstrates the need to develop a transdisciplinary process at a regional level; however, there is also a need to understand the capacities and limitations of the promoters of TD. Therefore, further spatial analysis should focus on identifying those parts of the montado area where severe decline has occurred, so that these areas can be given prioritized attention. Working at a regional scale necessarily means dealing with a very large sized resource system, with a consequent disadvantage for collective action. (Amblard, 2012; Nagendra and Ostrom, 2014; Bennett and Gosnell, 2015). This is one of the main challenges in our case study that could be tackled by defining a typology of the montado, designing a tailored transdisciplinary process for each type, and identifying which properties should be prioritized for participation in the transdisciplinary process. Such a narrowing of the range of actors and areas of the montado could reduce the challenges of achieving collective actions by dealing with a more manageable resource size.

By applying the SES framework to the montado case-study we were able to combine different sources of information in a systematic manner useful to understand the complexity of the sustainability issue to be dealt with by TD (Seifferta and Loch, 2005; Gaziulusoy and Boyle, 2013). The existence of a list of second-tier variables for each subsystem of the framework promotes a reflection process regarding the variable utility and its status in the current context of the problem. The main difficulty here was the lack of a clear definition of each second-tier variable. Today, the sole way to grasp their definition is by understanding how other authors have characterized it (Table 1). The SES framework focus on the interactions between the social and ecological systems made explicit, in our case study, the lack of studies that explore such interactions. As Guerrero and Wilson (2017) concludes a poor understanding of the interactions between the social and ecological system is likely to result in inadequate implementation strategies and failure to respond to the existing opportunities and challenges. The same conclusion is valid for the promoters of a TD research process, and as Gaziulusoy and Boyle (2013) concludes, tools that help attain a systematic or holistic perspective are scarce. The SES framework used in a transdisciplinary can be a starting point to build the necessary holistic systems perspective argued by Williams et al. (2017) and needed to better understand and act upon a sustainability problem.

\section{Conclusions}

Our study illustrates how the SES framework can be applied to 
TD due to the focus on social-ecological interactions that allows the systematic exploration of complexity, the discussion of how current condition might affect TD, and the identification of aspects that requires further investigation. Applying the SES framework while trying to grasp the complexity of the sustainability problem can be an effective exercise for the promoters of TD. Therefore, we suggest the inclusion of the SES framework in the initial phase of a transdisciplinary process. Finally, the SES framework can also be useful for monitoring and evaluating the impact of TD by reanalysing the same variables after the application of a transdisciplinary process.

\section{Acknowledgements}

The Portuguese National Foundation for Science and Technology (FCT) supported the work of Helena Guimarães [grant number SFRH/BPD/95556/2013], Diana Surová [SFRH/BPD/77649/2011] and Federica Ravera [SFRH/BPD/104956/2014]. National Funds under the Project UID/AGR/00115/2013 funded this work.

\section{References}

Agrawal, A., 2001. Common property institutions and sustainable governance of resources. World Dev. 29 (10), 1649-1672. https://doi.org/10.1016/S0305$750 X(01) 00063-8$.

Almeida, M., Guerra, C., Pinto-Correia, T., 2013. Unfolding relations between land cover and farm management: high nature value assessment in complex silvopastoral systems. Nor. J. Geogr. 113 (2), 97-108. https://doi.org/10.1080 00167223.2013.848611.

Amaral, L., 1994. Portugal e o passado: política agrária, grupos de pressão e evolução da agricultura portuguesa durante o Estado Novo (1950-1973). Análise Soc. 29 (128), 889-906.

Amblard, L., 2012. The potential of collective action for the control of nonpoint source pollution in European rural areas. In: Proceedings of the Conference "Design and Dynamics of Institutions for Collective Action", November 29-December 1. Utrecht University.

Barroso, F., Menezes, H., Pinto-Correia, T., 2013. How can the land managers and his multi-stakeholder network at the farm level influence the multifunctional transitions pathways? Spanish J. Rural Dev. 4 (4), 35-48. https://doi.org/ 10.5261/2013.GEN4.04.

Baur, I., Binder, C.R., 2013. Adapting to socioeconomic developments by changing rules in the governance of common property pastures in the Swiss Alps. Ecol. Soc. 18 (4), 60. https://doi.org/10.5751/ES-05689-180460.

Bennett, D.E., Gosnell, H., 2015. Integrating multiple perspectives on payments for ecosystem services through a social-ecological systems framework. Ecol. Econ. 116, 172-181. https://doi.org/10.1016/j.ecolecon.2015.04.019.

Binder, C.R., Hinkel, J., Bots, P.W.G., Pahl-Wostl, C., 2013. Comparison of frameworks for analysing social-ecological systems. Ecol. Soc. 18 (4), 26. https://doi.org/10. 5751/ES-05551-180426.

Bugalho, M., Caldeira, M.C., Pereira, J.S., Aronson, J., Pausas, J., 2011. Mediterranean cork oak savannas require human use to sustain biodiversity and ecosystem services. Front. Ecol. Environ. 9 (5), 278-286. https://doi.org/10.1890/100084.

Carew, A.L., Wickson, F., 2010. The TD wheel: a heuristic to shape, support and evaluate transdisciplinary research. Futures 42, 1146-1155. https://doi.org 10.1016/j.futures.2010.04.02.

Cutileiro, J., 1972. Ricos e pobres no Alentejo: uma análise de estrutura social. Análise Soc. 9 (34), 265-292.

Ferraz-de-Oliveira, M.I., Lamy, E., Bugalho, M.N., Vaz, M., Pinheiro, C., Cancela d'Abreu, M., Capela e Silva, F., Sales-Baptista, E., 2013. Assessing foraging strategies of herbivores in Mediterranean oak woodlands: a review of key issues and selected methodologies. Agrofor. Syst. 87, 1421-1437. https://doi.org/ 10.1007/s10457-013-9648-3.

Fleischman, F.D., Boenning, K., Garcia-Lopez, G.A., Mincey, S., Schmitt-Harsh, M., Daedlow, K., Lopez, M., Basurto, X., Fischer, B., Ostrom, E., 2010. Disturbance, response, and persistence in self-organized forested communities: analysis of robustness and resilience in five communities in southern Indiana. Ecol. Soc. 15 (4), 9. http://www.ecologyandsociety.org/vol15/iss4/art9/.

Fragoso, R., Marques, E., Luca, M.R., Martins, M.B., Jorge, R., 2011. The economic effects of common agricultural policy on Mediterranean montado/dehesa ecosystem. J. Pol. Model. 33, 311-327. https://doi.org/10.1016 j.jpolmod.2010.12.007.

Gaziulusoy, A.I., Boyle, C., 2013. Proposing a heuristic reflective tool for reviewing literature in transdisciplinary research for sustainability. J. Clean. Prod. 48 139-147. https://doi.org/10.1016/j.jclepro.2012.04.013.

Godinho, S., Gil, A., Guiomar, N., Neves, N., Pinto-Correia, T., 2016a. A remote sensing-based approach to estimating montado canopy density using the FCD model: a contribution to identifying HNV farmlands in southern Portugal. Agrofor. Syst. 90, 23-34. https://doi.org/10.1007/s10457-014-9769-3.

Godinho, S., Guiomar, N., Machado, R., Santos, P., Sá-Sousa, P., Fernandes, J.P.,
Neves, N., Pinto-Correia, T., 2016b. Assessment of environment, land management, and spatial variables on recent changes in montado land cover in southern Portugal. Agrofor. Syst. 90, 177-192. https://doi.org/10.1007/s10457014-9757-7.

Gutiérrez, N.L., Hilborn, R., Defeo, O., 2011. Leadership, social capital and incentives promote successful fisheries. Nature 470, 386-389. https://doi.org/10.1038/ nature09689.

Guerrero, A.M., Wilson, K.A., 2017. Using a social-ecological framework to inform the implementation of conservation plans. Conserv. Biol. 31 (2), 290-301.

Hadorn, G.H., Hoffmann-Riem, H., Biber-Klemm, S., Grossenbacher-Mansuy, W., Joye, D., Pohl, C., Wiesmann, U., Zemp, E., 2008. Handbook of Transdisciplinary Research. Springer, New York. https://doi.org/10.1007/978-1-4020-6699-3. Springer.

Klein, J.T., Grossenbacher-Mansuy, W., Häberli, R., Bill, A., Scholz, R.W., Welti, M., 2001. Transdisciplinarity: Joint Problem Solving Among Science, Technology, and Society. An Effective Way for Managing Complexity. Springer, Basel. https:// doi.org/10.1007/978-3-0348-8419-8.

Lang, D.J., Wiek, A., Bergmann, M., Stauffacher, M., Martens, P., Moll, Swilling, M., Thomas, C.P., 2012. Transdisciplinary research in sustainability science: practice, principles, and challenges. Sustain. Sci. 7 (S1), 25-43. https://doi.org/10.1007/ s11625-011-0149-X.

Manring, S.L., 2014. The role of universities in developing interdisciplinary action research collaborations to understand and manage resilient social-ecological systems. J. Clean. Prod. 64, 125-135. https://doi.org/10.1016/ j.jclepro.2013.07.010.

Mestre, A., Vogtlander, J., 2013. Eco-efficient value creation of cork products: an LCA-based method for design intervention. J. Clean. Prod. 57, 103-114. https:// doi.org/10.1016/j.jclepro.2013.04.023.

McGinnis, M.D., Ostrom, E., 2014. Social-ecological system framework: initial changes and continuing challenges. Ecol. Soc. 19 (2), 30. https://doi.org/10.5751/ ES-06387-190230.

McKee, A., Guimarães, M.H., Pinto-Correia, T., 2015. Social capital accumulation and the role of the researcher: an example of a transdisciplinary visioning process for the future of agriculture in Europe. Environ. Sci. Pol. 50, 88-99. https:// doi.org/10.1016/j.envsci.2015.02.006.

Nagendra, H., Ostrom, E., 2014. Applying the social-ecological system framework to the diagnosis of urban lake commons in Bangalore, India. Ecol. Soc. 19 (2), 67. https://doi.org/10.5751/ES-06582-190267.

Ostrom, E., 1990. Governing the Commons: the Evolution of Institutions for Collective Action. Cambridge University Press, Cambridge. https://doi.org/10.1017 CB09780511807763.

Ostrom, E., 2009. A general framework for analyzing sustainability of socialecological systems. Science 325, 419-422. https://doi.org/10.1126/ science.1172133.

Pereira, P., Godinho, C., Roque, I., Rabaça, J.E., 2015. O Montado e as aves - Boas práticas para uma gestão sustentável. LabOr-ICAAM, Universidade de Évora, Câmara Municipal de Coruche, Coruche.

Pereira, P.M., Pires da Fonseca, M., 2003. Nature vs. nurture: the making of the montado ecosystem. Conserv. Ecol. 7 (3), 7. http://www.consecol.org/vol7/iss3/ art7.

Petty, A.M., Isendahl, C., Brenkert-Smith, H., Goldstein, D.J., Rhemtulla, J.M., Rahman, S.A., Kumasi, T.C., 2015. Applying historical ecology to environmental management institutions: lessons from two case studies of landscape fire management. Global Environ. Change 31, 1-10. https://doi.org/10.1016/ j.gloenvcha.2014.11.004.

Pinheiro, A.C., Ribeiro, N.A., Surový, P., Ferreira, A.G., 2008. Economic implications of different cork oak forest management system. Int. J. Sustain. Soc. 1 (2), 149-157. https://doi.org/10.1504/IJSSoc.2008.022571.

Pinto-Correia, T., Godinho, S., 2013. Changing agriculture - changing landscapes: what is going on in the high valued montado landscapes of southern Portugal? In: Ortiz-Miranda, D., Moragues-Faus, A., Arnalte-Alegre, E. (Eds.), Agriculture in Mediterranean Europe: between Old and New Paradigms. Emerald, Bingley, pp. 75-90.

Pinto-Correia, T., Ribeiro, N., Sá-Sousa, P., 2011. Introducing the montado, the cork and holm oak agroforestry system of Southern Portugal. Agrofor. Syst. 82, 99-104. https://doi.org/10.1007/s10457-011-9388-1.

Pinto-Correia, T., Ribeiro, N., Potes, J., 2013. Livro verde dos montados. ICAAM Instituto de Ciências Agrárias e Ambientais Mediterrânica. Universidade de Évora, Évora.

Pohl, C., 2011. What is progress in transdisciplinary research? Futures 43, 618-626. https://doi.org/10.1016/j.futures.2011.03.001.

Ribeiro, N.A., Surový, P., Pinheiro, A.C., 2010. Adaptive management on sustainability of cork oak woodlands. In: Manos, B., Paparizzos, K., Matsatsinis, N., Papathanasiou, J. (Eds.), Decision Support Systems in Agriculture, Food and the Environment: Trends, Applications and Advances. Information Science Reference, Hershey, pp, 437-449.

Risvoll, C., Fedreheim, G., Sandberg, A., BurnSilver, S., 2014. Does pastoralists' participation in the management of national parks in northern Norway contribute to adaptive governance? Ecol. Soc. 19 (2), 71. https://doi.org/10.5751/ ES-06658-190271.

Russell, A.W., Wickson, F., Carew, A.L., 2008. Transdisciplinarity: context, contradictions and capacity. Futures 40, 460-472. https://doi.org/10.1016 j.futures.2007.10.005.

Sá-Sousa, P., 2014. The Portuguese montado: conciliating ecological values with human demands within a dynamic agroforestry system. Ann. For. Sci. 71, 1-3. 
https://doi.org/10.1007/s13595-013-0338-0.

Schiller, S.R., Gonzalez, C., Flanigan, S., 2014. More than just a factor in transition processes? The role of collaboration in agriculture. In: Sutherland, L. Darnhofer, I., Wilson, G., Zagata, L. (Eds.), Transition Pathways towards Sustainability in European Agriculture. CABI International, Oxfordshire, pp. 83-96.

Seifferta, M.E.B., Loch, C., 2005. Systemic thinking in environmental management: support for sustainable development. J. Clean. Prod. 13 (2005), 1197-1202. https://doi.org/10.1016/j.jclepro.2004.07.004.

Surová, D., Pinto-Correia, T., 2008. Landscape preferences in the cork oak Montado region of Alentejo, southern Portugal: searching for valuable landscape characteristics for different user groups. Landsc. Res. 33 (3), 311-330. https:// doi.org/10.1080/01426390802045962.

Surová, D., Pinto-Correia, T., 2009. Use and assessment of the 'new' rural functions by land users and landowners of the Montado in Southern Portugal. Outlook Agric. 38 (2), 189-194. https://doi.org/10.5367/000000009788632340.

Vogt, J.M., Epstein, G.B., Mincey, S.K., Fischer, B.C., McCord, P., 2015. Putting the "E" in SES: unpacking the ecology in the Ostrom social-ecological system framework. Ecol. Soc. 20 (1), 55.

Williams, A., Kennedy, S., Philipp, F., Whiteman, G., 2017. Systems thinking: a review of sustainability management research. J. Clean. Prod. 148 (2017), 866-881. https://doi.org/10.1016/j.jclepro.2017.02.002. 